\title{
Simultaneous inheritance and expression of classical haemophilia A and type IIA von Willebrand's disease
}

\author{
AC BEDDALL, SM ENAYAT, CE WILLIAMS, PE SHORT, FGH HILL \\ From the Department of Haematology, Children's Hospital, Ladywood Middleway, Birmingham
}

SUMMARY A family is described in which the mother is a haemophilia carrier, the father has asymptomatic type IIA von Willebrand's disease, and their second son has simultaneously inherited both severe haemophilia and type IIA von Willebrand's disease. This is the first report of both diseases occurring simultaneously. The inheritance patterns and laboratory data on the family are presented and discussed.

Von Willebrand's disease is a heterogeneous group of autosomally transmitted bleeding disorders, which are characterised clinically by bruising and mucous membrane bleeding and by the laboratory findings of quantitative or qualitative abnormalities of factor VIII activities (FVIII procoagulant, VIII:C; related antigen, VIIIR:AG; von Willebrand factor, VIIIR:WF). ${ }^{12}$ Recently, a number of variant (type II) forms of von Willebrand's disease have been characterised by multimeric analysis of the von Willebrand protein (VIIIR:AG/VIIIR:WF) and by the quantitative aggregation of patients' platelets by ristocetin. ${ }^{34}$

In contrast, classical haemophilia $\mathrm{A}$ is inherited as an $\mathrm{X}$ linked recessive disorder and is characterised in its severest form by recurrent spontaneous haemarthroses and muscle bleeds. VIII: $\mathrm{C}$ values are low, but levels of VIIIR:AG and ristocetin induced platelet aggregation are usually normal. ${ }^{5}$ The inherited coagulation disorders are uncommon. The estimated incidence of classical haemophilia is 5-10 per 100000 population. ${ }^{6}$ Estimation of the incidence of von Willebrand's disease is difficult because of the existence of asymptomatic heterozygotes and its variable clinical expression.

We have recently identified a patient who has simultaneously inherited both classical haemophilia A and type IIA von Willebrand's disease. This is the first report of documented von Willebrand's disease and classical haemophilia in the same individual. The clinical, including inheritance pattern, and laboratory features are discussed.

Accepted for publication 13 June 1984

\section{Material and methods}

\section{SUBJECTS}

The propositus was referred because he had bled excessively from a torn frenulum and developed a large scalp haematoma after a small knock. There was a known maternal family history of haemophilia (Fig. 1). The family is of Afrocaribbean origin and

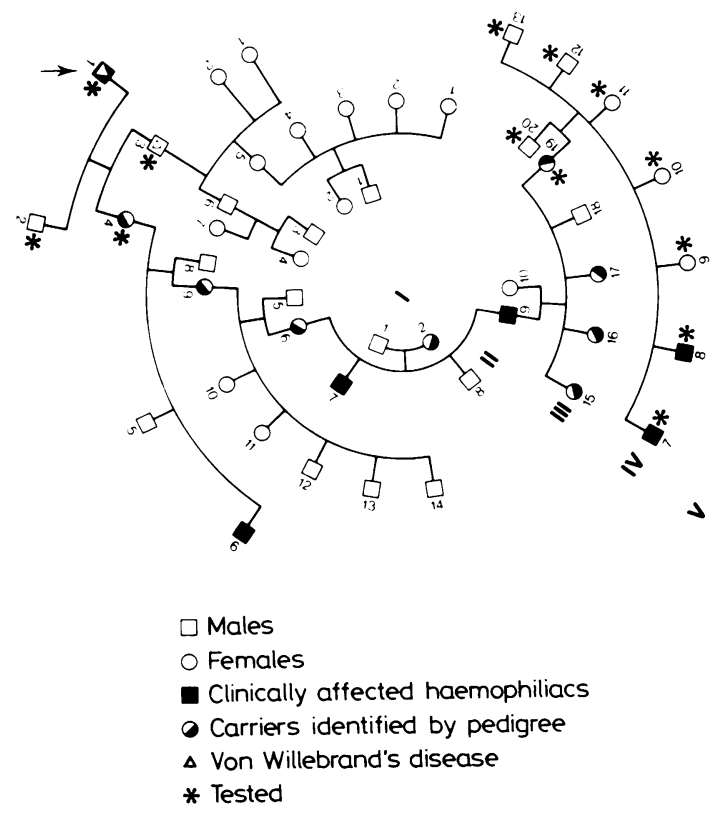

Fig. 1 Family pedigree. Propositus indicated by arrow. 
Results of coagulation studies

\begin{tabular}{|c|c|c|c|c|c|c|c|}
\hline Initial & Relationship & $\begin{array}{l}\text { Ivy bleeding time } \\
\text { (min) }\end{array}$ & $\begin{array}{l}P T T \\
(s)\end{array}$ & $\begin{array}{l}V I I I: C \\
(U / m l)\end{array}$ & $\begin{array}{l}\text { VIIIR:AG } \\
(U / m l)\end{array}$ & $\begin{array}{l}\text { VIIIR:WF } \\
(U / m l)\end{array}$ & $\begin{array}{l}\text { Migration ratio (by crossed } \\
\text { immunoelectrophoresis) }\end{array}$ \\
\hline $\begin{array}{l}\text { CC } \\
\text { LC } \\
\text { DC } \\
\text { CC } \\
\text { Norma }\end{array}$ & $\begin{array}{l}\text { Propositus } \\
\text { Father } \\
\text { Mother } \\
\text { Brother }\end{array}$ & $\begin{array}{l}4 \cdot 5 \\
3 \\
3 \\
3 \\
\text { up to } 7\end{array}$ & $\begin{array}{l}74 \\
31 \\
35 \\
34 \\
32\end{array}$ & $\begin{array}{l}0.00 \\
0.72 \\
0.42 \\
0.90 \\
0.5-1.50\end{array}$ & $\begin{array}{l}0.78 \\
1 \cdot 76 \\
1 \cdot 20 \\
1 \cdot 00 \\
0 \cdot 5-1 \cdot 50\end{array}$ & $\begin{array}{l}0.05 \\
0.05 \\
0.90 \\
0.90 \\
0.5-1 \cdot 50\end{array}$ & $\begin{array}{l}1 \cdot 50 \\
1 \cdot 30 \\
1 \cdot 00 \\
1 \cdot 00 \\
0.99 \pm 0 \cdot 11\end{array}$ \\
\hline
\end{tabular}

PTT $=$ partial thromboplastin time

the propositus' mother was related through her maternal grandmother to another local family who have a son with severe haemophilia (VIII:C $0 \mathrm{U} / \mathrm{ml}$; VIIIR:AG $1.80 \mathrm{U} / \mathrm{ml}$; VIIIR:WF $0.66 \mathrm{U} / \mathrm{ml}$ ). The propositus' mother had a brother who died, as a child, of a cerebral haemorrhage in Jamaica.

The propositus' father and brother had no clinical symptoms to suggest a bleeding disorder. The propositus' father, however, had not had any operations or extractions of his permanent dentitian. The father, brother, mother, and propositus were studied, but the father's relatives were unfortunately not available for testing.

\section{PLATELETS AND PLASMA}

Venous blood was obtained from family members and normal men as controls. Nine parts of blood were added to one part of $0 \cdot 11 \mathrm{M}$ sodium chloride. Platelet rich plasma was prepared by centrifuging $150 \mathrm{~g}$ for $10 \mathrm{~min}$ at room temperature and platelet poor plasma was prepared by centrifuging at $2700 \mathrm{~g}$ for $15 \mathrm{~min}$ at $4^{\circ} \mathrm{C}$. The standard for the factor VIII procoagulant activity (VIII:C) was a $100 \%$ reference plasma (Immuno Diagnostika) calibrated against the 10th British Factor VIII standard (VIII:C $0.65 \mathrm{IU} / \mathrm{ml}$ ); the standard for the factor VIII related antigen (VIIIR:AG) was the 10th British Standard (VIIIR:AG 0.80 IU $/ \mathrm{ml}$ ) and a pool of plasma from 30 normal men (VIIIR:AG 1.0
$\mathrm{IU} / \mathrm{ml}$ ). The latter was also used as the standard for the von Willebrand factor (VIIIR:WF) assay. Platelets were washed with EDTA tris buffer and concentrated by centrifuging on to $34 \% \mathrm{wt} / \mathrm{vol}$ bovine albumin. ${ }^{7}$ Platelets were washed four times before fixing with paraformaldehyde and used in the VIIIR:WF assay (see below).

Ristocetin was supplied by Lundbeck A/S, Denmark; and agarose was supplied by BDH Poole, Dorset. Rabbit antihuman VIII serum was supplied by Behringwerke and used in the VIIIR: AG crossed immunoelectrophoresis. Another antiserum (Dako rabbit antihuman FVIII immunoglobulin) was used unconjugated and conjugated in the VIIIR:AG ELISA assay. The same antibody labelled with ${ }^{125} I$ was used for identifying the VIIIR:AG multimers.

Bleeding time was measured by the modified Ivy technique. VIII:C was measured by a two stage assay using a Diagen kit (Diagnostic Reagents Ltd). VIIIR:AG was measured by an ELISA technique; and VIIIR:AG electrophoretic mobility was assessed by crossed immunoelectrophoresis. ${ }^{9}$ VIIIR:AG multimeric analysis was done as previously described $^{10}$ using a modification of the method of Ruggeri and Zimmerman." VIIIR:WF was measured using fixed platelets as described by Brinkhous and Read. ${ }^{12}$

Platelet aggregation studies were performed only on the father's platelet rich plasma, adjusted to a

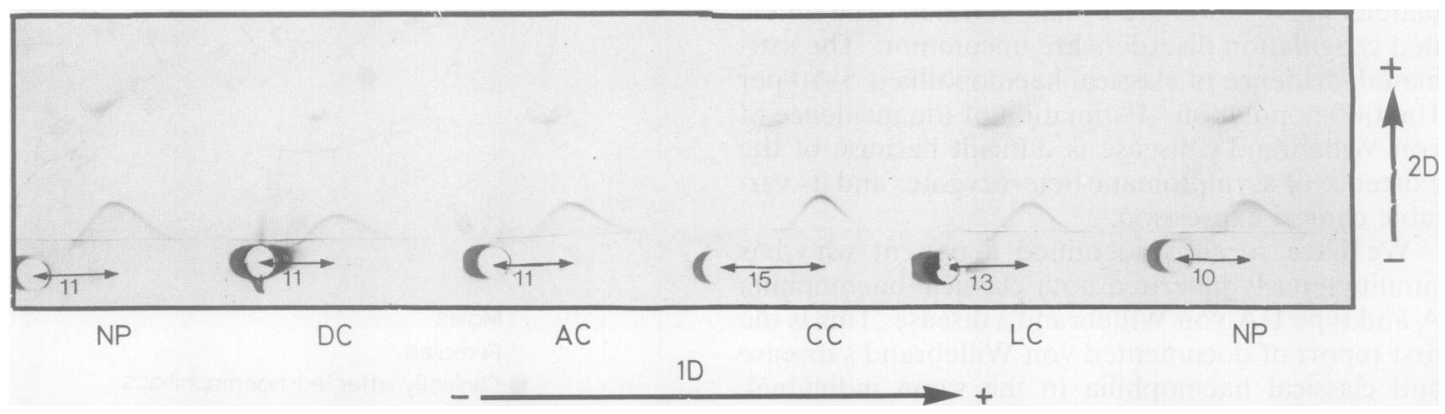

Fig. 2 Crossed immunoelectrophoresis of VIIIR:AG on propositus (CC), father (LC), mother (DC), brother (AC), and normal subject (NP). Directions of electrophoresis as shown. Figure below each arc indicates degree of migration (in mm) from centre of well to peak of precipitin arc. 
platelet count of $300 \times 10^{9} /$, using a dual channel aggregometer (Malin Electronics Ltd, Ayr, Scotland). Studies were performed with adenosine diphosphate (BDH), collagen (Hormon-Chemie, Munich), ristocetin (final concentrations 1.25 and $1.5 \mathrm{mg} / \mathrm{ml}$ ), bovine fibrinogen (final concentration $1.7 \mathrm{mg} / \mathrm{ml}$ ) and thrombin (final concentration 1.7 units/ml). Aggregation patterns were compared with those of platelet rich plasma from a normal control tested under identical conditions.

\section{Results}

The pedigree and results of the coagulation studies are shown in Fig. 1 and the Table, respectively.

The propositus (CC) had VIII:C and VIIIR:AG values typical of severe haemophilia, but was unusual in that he lacked VIIIR:WF. His mother (DC) had a normal VIIIR:AG value but reduced VIII:C, with a VIII:C and VIIIR:AG ratio of 0.32 , similar to that seen in haemophilia carriers. ${ }^{13}$ She, unlike her son, had a normal VIIIR:WF value, whereas the father (LC) had almost absent VIIIR:WF despite normal VIII:C and VIIIR:AG values. Platelet aggregation studies on platelet rich plasma from the father (LC) were normal with collagen, adenosine diphosphate, bovine fibrinogen, and thrombin, but absent with ristocetin.

Although VIIIR:AG values were normal in all family members, crossed immunoelectrophoresis patterns were abnormal for the propositus and his father. In plasma from these, an abnormal precipitin arc characterised by a decrease in the electrophoret- ically slower high molecular weight VIIIR:AG forms and a more anodal peak were seen (Fig. 2). Migration ratios (ratio of anodal migration of test to control) were also raised.

Multimeric analysis confirmed the absence of the larger and intermediate molecular weight multimers in the propositus and his father (Fig. 3), but the mother and brother had normal multimeric analysis. The absence of high and intermediate multimers is typical of type IIA von Willebrand's disease. ${ }^{311}$ The father therefore appears to have asymptomatic type IIA von Willebrand's disease, while his son has this and haemophilia. In normal plasma, the lower bands consist of a triplet configuration (Fig. 3). Those of the propositus and his father contrast with those of the normal subject (NP), the mother (DC), and the brother (AC) in that the central band and the a and b sub-bands of the triplet were more densely staining. VIIIR:AG multimeric analysis for the mother (DC) and the brother (AC) was normal.

\section{Discussion}

Type II von Willebrand's disease is characterised by a qualitative defect of the von Willebrand protein (VIIIR:AG/VIIIR:WF) detectable by crossed immunoelectrophoresis and sodium dodecyl sulphate agarose gel electrophoresis. Recently, patients with type II von Willebrand's disease have been subdivided. ${ }^{34}$ The IIA variants show an absence of large and intermediate VIIIR:AG multimers in both plasma and platelets; ${ }^{3} 11$ VIIIR:WF and ristocetin induced platelet aggregation are absent or low. The

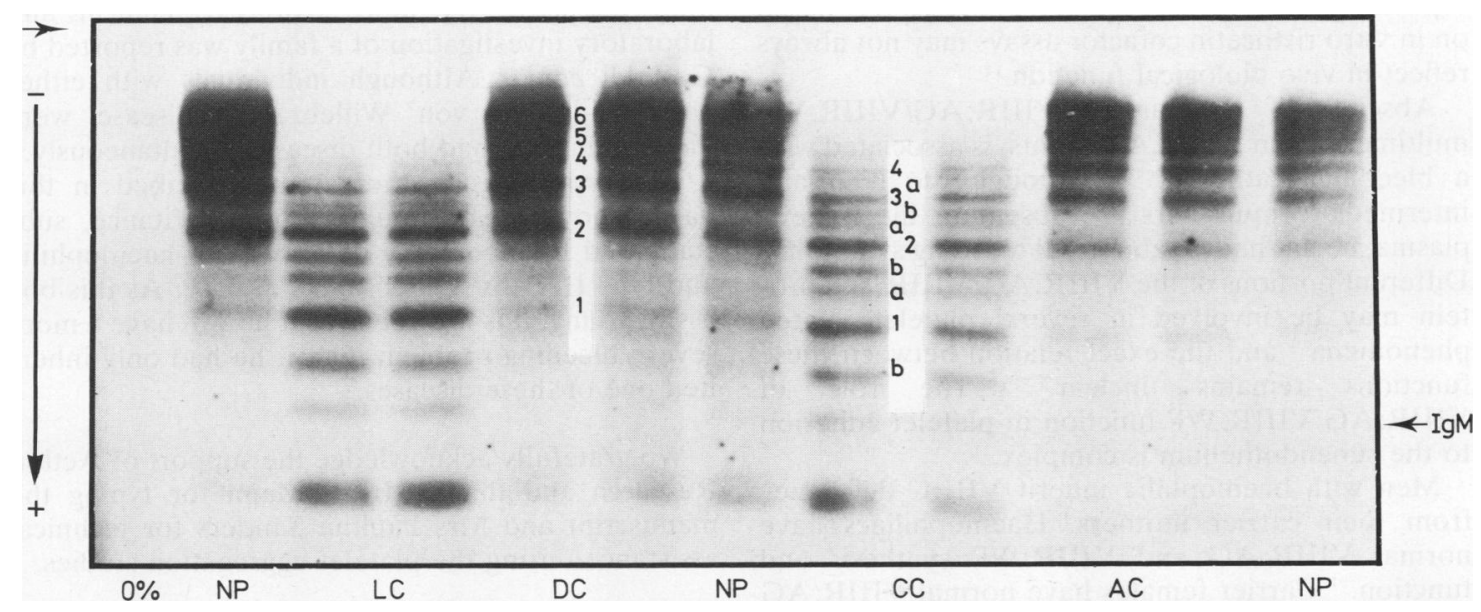

Fig. 3 VIIIR:AG multimeric analysis patterns for the propositus (CC), father (LC), mother (DC), and brother (AC) and normal subject (NP). Direction of electrophoresis as shown; upper arrow indicates gel interface and position of IgM molecular weight marker as shown. 
type IIB variants lack the large multimers in their plasma but not in the platelets, and ristocetin induced platelet aggregation occurs with normal and subnormal ristocetin concentrations. ${ }^{3}$ In both IIA and IIB variants, as well as in normal plasma, each multimer has a triplet configuration represented by a central band flanked by two subsidiary bands (designated $b$ below and a above the central band). Although the mobility of the triplets in IIA, IIB, and normal plasma is the same, ${ }^{113}$ differences in triplet configuration are seen between different IIA patients and normal subjects. ${ }^{114} \mathrm{~A}$ further variant, type IIC, has recently been described. ${ }^{4}$ This condition is inherited in an autosomal recessive way, and as well as lacking the larger multimers, the multimer mobility is different and there is a doublet rather than a triplet configuration.

The propositus and his father fulfil some of the criteria for type IIA von Willebrand's disease. The propositus, but not his brother, has inherited this disorder, showing an autosomal dominant pattern. The propositus appears also to have inherited severe haemophilia from his mother. The normal bleeding time of the propositus and his father is most unusual in the light of findings indicative of type IIA von Willebrand's disease. This may partly explain the lack of previous abnormal bleeding in the father, although, as yet, he has not had any operative challenge. Measurements of bleeding time may vary considerably in the same individual, ${ }^{15}$ but on repeated testing, the propositus and his father have always had normal bleeding times. Disparity between the bleeding time and in vitro VIIIR:WF assays in von Willebrand's disease has been reported, ${ }^{16}$ and measurement of VIIIR:WF based on in vitro ristocetin cofactor assays may not always reflect in vivo biological function. ${ }^{17}$

Absence of the largest VIIIR:AG/VIIIR:WF multimers, as in type IIA patients, is associated with a bleeding diathesis. ${ }^{1819}$ Although the high and intermediate multimers are absent in the father's plasma, he has had no abnormal bleeding symptoms. Different portions of the VIIIR:AG/VIIIR:WF protein may be involved in several platelet related phenomena ${ }^{20}$ and the exact relation between these functions remains unclear. ${ }^{17}$ The role of VIIIR:AG/VIIIR:WF function in platelet adhesion to the subendothelium is complex.21

Men with haemophilia inherit VIII:C deficiency from their carrier mothers. Haemophiliacs have normal VIIIR:AG and VIIIR:WF synthesis and function. ${ }^{17}$ Carrier females have normal VIIIR:AG values but VIII: $C$ may be reduced because of random inactivation of normal and abnormal $\mathrm{X}$ chromosomes as postulated by Lyon. Identification of a proportion of haemophilia carriers can be made on the basis of VIII:C:VIIIR:AG ratios. ${ }^{12}$ The propositus in this report has inherited haemophilia from his carrier mother and, although he shows a normal VIIIR:AG value, this is qualitatively abnormal (low VIIIR:AG, abnormal multimer pattern). As the father shows similar VIIIR:AG/ VIIIR:WF abnormalities, the father's gene is being expressed in a dominant way, while the mother's normal gene for VIIIR:AG is not expressed.

Haemophilia A and von Willebrand's disease in the same kindred has been reported previously. Quick and Adlam ${ }^{22}$ reported a family with haemophilia A in which the presence of von Willebrand's disease was suggested by clinical bleeding pattern, inheritance pattern, prolonged bleeding time, and a positive tourniquet test. No individual was known to have inherited both disorders. Geiger and Rath $^{23}$ reported a kindred with factor VIII deficiency in which von Willebrand's disease was inferred because of autosomal inheritance and prolonged bleeding time. Two children were thought to have both disorders because of clinical symptoms and prolonged bleeding times, although the latter was occasionally normal. Both of these studies, however, were performed before the availability of assays for VIIIR:AG, VIIIR:WF, and quantitative platelet agglutination with ristocetin and therefore the claim cannot be fully substantiated. The possibility of aspirin ingestion causing the prolonged bleeding time cannot be excluded, and prolonged bleeding times have been recorded in haemophiliacs. ${ }^{24}$ Holmberg and Nilsson reported several cases of well documented haemophilia A and von Willebrand's disease in a Swedish family, but no individual had both diseases. ${ }^{25} \mathrm{~A}$ more extensive clinical and laboratory investigation of a family was reported by Gastaldi et al. ${ }^{26}$ Although individuals with either haemophilia or von Willebrand's disease were identified, none had both diseases simultaneously.

The propositus in the family described in this paper shows clear simultaneous inheritance, substantiated by laboratory data, of both haemophilia and type IIA von Willebrand's disease. As this boy is still young, it is not yet clear if he will have a more severe bleeding problem than if he had only inherited one of these diseases.

We gratefully acknowledge the support of Action Research and thank Mrs P Mann for typing the manuscript and Mrs Pauline Sanders for technical assistance during the platelet aggregation studies.

\footnotetext{
References

'Bloom AL. The von Willebrand syndrome. Semin Hematol $1980 ; 17: 215-27$.

${ }^{2}$ Miller $\mathrm{CH}$, Graham JB, Goldin LR, Elston RC. Genetics of
} 
classic von Willebrand's disease: 1 . Phenotypic variation within families. Blood 1979;54:117-36.

${ }^{3}$ Ruggeri ZM, Zimmerman TS. Variant von Willebrand's disease. Characterisation of two subtypes by analysis of multimeric composition of factor VIII/von Willebrand factor in plasma and platelets. $J$ Clin Invest 1980;65:1318-25.

${ }^{4}$ Ruggeri ZM, Nilsson IM, Lombardi R, Holmberg L, Zimmerman TS. Aberrant multimeric structure of von Willebrand factor in a new variant of von Willebrand's disease (type IIC). $J$ Clin Invest 1982; 70:1124-7.

${ }^{5}$ Bloom AL, Thomas DP. (eds) Haemostasis and thrombosis. Edinburgh: Churchill Livingstone, 1981.

- Bloom AL, ed. The haemophilias. Edinburgh: Churchill Livingstone, 1982.

' Hutton RA, Howard MA, Deykin D, Hardisty RM. Methods for the separation of platelets from plasma. A comparison of functional and morphological integrity. Thrombosis et Diathesis Haemorrhagica 1974;55:1056-9.

${ }^{8}$ Short PE, Williams CE, Picken AM, Hill FGH. Factor VIII related antigen: an improved enzyme immunoassay. Med Lab Sci 1982;39:351-5.

' Enayat MS, Hill FGH. Qualitative VIIIR:AG function screening of multiple samples by two dimensional crossed immunoelectrophoresis technique. Med Lab Sci 1982;39:357-62.

${ }^{10}$ Enayat MS, Hill FGH. Analysis of the complexity of the multimeric structure of factor VIII related antigen/von Willebrand protein using a modified electrophoretic technique. J Clin Pathol 1983;36:915-9.

" Ruggeri ZM, Zimmerman TS. The complex multimeric composition of factor VIII/von Willebrand factor. Blood 1981;57:1140-3.

${ }^{12}$ Brinkhous KM, Read MS. Preservation of platelet receptors for stable platelet preparations for von Willebrand factor assays. Thromb Res 1978;13:591-7.

${ }^{13}$ Klein HG, Aledort LM, Bouma BN, Hoyer LW, Zimmerman TS, De Mets DL. A co-operative study for the detection of the carrier state of classic haemophilia. $N$ Engl $J$ Med 1977;296:959-62.

is Hill FGH, Enayat MS, George AJ. Investigation including VIIIR:AG multimeric analysis of large kindred with type IIA von Willebrand's disease showing a dominant inheritance and similar gene expression in four generations. Thromb Haemos- tas 1983;50:753-9.

${ }^{15}$ Abildgard CF, Suzuki Z, Harrison J, Jefcoat K, Zimmerman TS. Serial studies in von Willebrand's disease: variability versus 'variants'. Blood 1980;56:712-6.

${ }^{16}$ Ratnoff OD, Bennett B. Clues to the pathogenesis of bleeding in von Willebrand's disease. $N$ Engl J Med 1973;289:1182-3.

${ }^{17}$ Hoyer LW. The factor VIII complex: Structure and function. Blood 1981;58:1-13.

${ }^{18}$ Gralnick HR, Williams SB, Morisako DK. Effect of the multimeric structure of the factor VIII/von Willebrand factor protein on binding to platelets. Blood 1981;58:387-97.

${ }^{19}$ Meyer D, Obert B, Pietu G, Lavergne JM, Zimmerman TS. Multimeric structure of factor VIIV/von Willebrand factor in von Willebrand's disease. J Lab Clin Med 1980;95:590-602.

${ }^{20}$ Ogata K, Saito H, Ratnoff OD. The relationship of antihaemophilic factor (Factor VIII) that supports ristocetin induced platelet agglutination (Factor VIIIR:RC) and platelet retention by glass beads as demonstrated by a monoclonal antibody. Blood 1983;61:27-35.

${ }^{21}$ Meyer D, Baumgartner HR. Role of von Willebrand factor in platelet adhesion to the subendothelium. Br J Haematol 1983;54:1-9.

${ }^{22}$ Quick AJ, Adlam RT. Coexistence of von Willebrand's disease and haemophilia in a family. JAMA 1963;185:635-9

${ }^{23}$ Geiger MT, Rath CE. Occurrence of two haemorrhagic disorders with antihaemophilic factor (AHF) deficiency in the same family: Classical haemophilia and von Willebrand's disease. J Lab Clin Med 1963;61:424-36.

${ }^{24}$ Eyster ME, Gordon RA, Ballard JO. The bleeding time is longer than normal in haemophilia. Blood 1981;58:719-23.

${ }^{25}$ Holmberg L, Nilsson IM. Haemophilia A and von Willebrand's disease in a Swedish family. Acta Paediatr Scand 1972;61:517-25.

${ }^{26}$ Gastaldi G, Rasore-Quartino A, Gallett A, Campanella A, Barone E, Mannucci PM. Coexistence of haemophilia A and von Willebrand's disease in the same kindred. Scand $J$ Haematol 1978;20:423-8.

Requests for reprints to: Dr Frank GH Hill, Department of Haematology, The Children's Hospital, Ladywood Middleway, Ladywood, Birmingham B16 8ET, England. 